DOI:10.31696/2072-8271-2020-1-1-46-379-389

\title{
The Dilemma of Sino-Myanmar Relations: The Case of Myitsone Hydropower Dam Project
}

\section{Wai Yan Phyo Naing}

PhD Student, NRU HSE, Russia, Moscow, Myanmar, ywai@hse.ru, https://orcid.org/0000-0001-8358-1258

Abstract: In 2011, President Thein Sein declared prospects for the Myitsone Dam General Project suspension during his tenure without any discussion with the Chinese government. This article explores the outcomes from the Myitsone Dam general project in the context of the Sino-Myanmar relations. The factors specific to the electricity production in the context of the geopolitical significance of the Ayeyarwaddy river are explored. The article also focuses on possible solutions if two governments decided to resume the Myitsone Project in the future. Therefore, to investigate the hidden potential of the Myitsone Dam project is a timely and relevant exercise.

Keywords: Myitsone, Ayeyarwaddy, U Thein Sein, Daw Aung San Suu Kyi, China Power Investment Corporation, NLD government

\section{Дилемма китайско-мьянманских отношений: проект строительства плотины на Мийтсоне}

\section{Вей Ян Пьё Найнг}

аспирант НИУ ВШЭ, Россия, Москва, Мьянма, уwai@hse.ru https://orcid.org/0000-0001-8358-1258

Аннотация: В 2011 г. президент Тейн Сейн объявил о приостановке проекта строительства плотины на Мийтсоне в течение срока его полномочий без обсуждения этого вопроса с правительством Китая. В статье исследованы результаты реализации проекта строительства плотины на Мийтсоне в контексте китайско-мьянманского сотрудничества. Выявлены факторы важности производства электроэнергии в контексте геополитической значимости реки Иравади. Помимо этого, статья дает оценку возможных сценарных вариантов развития событий, если правительства двух стран решат возобновить реализацию проекта. Таким образом, выявить скрытый потенциал проекта плотины на Мийтсоне является важной и своевременной задачей.

Ключевые слова: Мийтсон, Иравади, Тейн Сейн, Аун Сан Су Чжи, Сhina Power Investment Corporation, правительство НЛД

(C) Wai Yan Phyo Naing, 2020. 


\section{Introduction}

Since President Thein Sein's administration ascension to power in 2011, he has promoted Democratic norms and values in Myanmar. As a result, media and activists got the freedom to write and freedom of speech on the government plans and projects. In particular, Chinese mega projects became a focal point of interest for the anti-government groups because of the growing anti-Chinese sentiments predating the Military government era. On the other hand, Sino-Myanmar relations were primarily based on the government-to-government basis, never paying attention to the sentiments of Myanmar citizens. President Thein Sein announced the suspension of the Myitsone Dam General Project on 30 September 2011 following Myanmar's public opinion. The Chinese government was disappointed with Myanmar president's decision because he did not discuss his intentions with Beijing ${ }^{1}$. Consequently, the dialogue between China and Myanmar entered the most turbulent period in their relations within two decades.

The suspension of the Myitsone has become a crucial issue in the contemporary two countries' relations. Why are the Myitsone and the Ayeyarwaddy River important for Myanmar? What is the interest of China in the Myitsone project? Moreover, why is it important to analyze contemporary Sino-Myanmar relations in the light of the Myitsone Hydropower Dam Project? A voluminous body of literature produced by the Myanmar, Chinese, and international scholars is pivotal in analyzing these questions. There have been several major works researching the Myitsone $^{2}$. Unfortunately, there are no studies dedicated to the potential advantages of the Myitsone Dam. So far, the Myitsone Dam project has been perceived as a thorn in Sino-Myanmar relations. Yun $\mathrm{Sun}^{3}$ has investigated both sides, including interviews with Chinese and Myanmar officials and activists. She mentioned Beijing's opinion that the cancellation of the project was the result of Western influence on Sino-Myanmar relations. To support her conclusion, she pointed at the Wikileaks report that the U.S embassy supported the anti-Myitsone activities in Myanmar. Also, she did not point out the possible advantages for both sides if the National League for Democracy Party's (NLD) government recalled the suspension of the Myitsone Dam project in the future.

However, when the NLD became the ruling party in Myanmar, they abstained from making any comments on the project due to sensitive points connected to the Myitsone Dam project. In this article, the author points out possible advantages for both countries if the two governments restart the project in the future again. 


\section{History of Myitsone}

After lengthy negotiation between both Myanmar and China's special test groups', the Myitsone Dam General Project initial plan reached the state level meeting agenda when Chinese President $\mathrm{Hu}$ Jintao met Myanmar government leader Senior General Than Shwe on the sideline of Asian-African summit during 2005 . On 16 June 2009, Myanmar Ambassador in Beijing and the President of the China Power Investment (CPI) signed the "Memorandum of Understanding" (MOU) for the development, operation, and transfer of the Hydropower Projects in May Hka, Maili Hka and upstream of the Myitsone area (the junction of May Hka and Maili Hka $)^{5}$. The Vice-chairman of the Myanmar State Peace and Development Council was also present at the ceremony during his state visit to Beijing ${ }^{6}$. When the then Chinese Vice-President $\mathrm{Xi}$ Jinping visited the Naypyidaw, the two countries' officials held the signing ceremony for the final agreements on Myitsone and other six hydropower dam projects ${ }^{7}$.

According to the final agreement, the Chinese Power Investment Corporation took $80 \%$ of shares, while Myanmar's Ministry of Electrical Power (1) (MEP-1) held 15\% of shares. The rest of the shares (5\%) went to the Asia World Myanmar, which was the general contractor and stockbroker for both sides. ${ }^{8}$ However, the appendix of the Journal of Current Southeast Asian Affairs (2012), indicated that 70:20:10 ratio of shares went to the CPI, Myanmar's Ministry, and Asia World Myanmar company. ${ }^{9}$ The discrepancy in numbers provided can be explained by the fact that the actual agreement of the Myitsone Hydropower Dam Project never was publicly revealed.

The project's contract set the waiting period at 50 years as the Build-Operate-Transfer (BOT) system. After that, China will hand over the whole project to Myanmar at no cost. ${ }^{10}$ According to the project plan, there will be seven hydropower dams. The construction started on the Ayeyarwaddy River. One dam is located in Myitsone area, five more dams above the Myitsone (two in Maili Hka river and three in Mai Hka river), and one in Laiza ${ }^{11}$. After completing all technical works and installations, seven dams can produce 184,00 Mega Watt per year. Only the Myitsone plan is going to produce $6000 \mathrm{MW}$, and this is the highest power out-put among all seven constructions ${ }^{12}$. Chan, Debby S.W also mentioned that the Myitsone Dam's storage area would cover $766 \mathrm{~km} 2$ and it is slightly bigger than Singapore. This area also includes the homeland of 18,000 peoples from 47 villages $^{13}$. However, international 
and local activists pay attention only to Myitsone Dam among all projects.

The amount of investment for seven dams reached about 20 billion US\$. The structure of the main dam's body plan estimated at 3.6 billion US\$. Here, the apparent contradiction is evident from different sources. In BBC's interview with the former Vice-Minister of Myanmar's MEP (1), he answered that the 7.2 billion US\$ comprised the investment only for the Myitsone Dam ${ }^{14}$. If the construction completed in 2019 as it was planned originally, the Myitsone's structure would be included in the World's 15 largest hydropower plant. According to Laur Kiik, the total output is almost equal to the massive Chinese Three Gorges ${ }^{15}$. The agreement specifies that Myanmar will receive $600 \mathrm{MW}(10 \%$ of total amount) electricity from the Myitsone Dam, and they can purchase as much as they want from the total MW. Therefore, literally, 90\% of the electricity will be imported to the Yunnan province directly ${ }^{16}$. It is the central argument which is accentuated by the anti-Myitsone activists.

\section{The Role of the Ayeyarwaddy River in Myanmar}

The researchers who investigate to the Myitsone Hydropower Dam project cannot stress enough how important the Ayayarwaddy River and Myitsone landscapes are for Myanmar. The Ayeyarwaddy is the lifeblood water artery and the National Landmark for Myanmar. It is about $2,170 \mathrm{~km}$ long stretching from North to South of Myanmar. ${ }^{17}$ The N'mai and Mali Hka rivers replenish the Ayayarwaddy by originating in the Himalaya glacier. Early civilizational development in Myanmar mostly happened along the Ayeyarwaddy River. The Last Myanmar Kingdom with its capital, Mandalay, is located beside the Ayeyarwaddy River. Just as Mandalay, Bagan (the First Myanmar Empire's City), Tharakhittara, Amapuram, and Pyuu also have thrived along the bank of the Ayeyarwaddy ${ }^{18}$ as it passes through Magway, Bago and Ayeyarwadday Regional Division before flowing to the Andaman Sea. The Basin of the Ayeryarwaddy River of the Ayeyarwaddy Division is also the main riceproducing area.

The Ayeyarwaddy River provides livelihood for farmers and fishermen who live along the river. Just as the Ayeyarwaddy is important, Myitsone Landscape is also famous as a national landmark not only for the Kachin State, but also for Myanmar. Myitsone is located $50 \mathrm{~km}$ above Myitkyina city, the capital of Kachin State. The construction of the Myitsone Hydropower dam is going to spread almost over the Myitsone Landmark area. Therefore, the Myitsone Project has attracted 
the people's attention as national concerns flared, sustained by cultural and national sentiments. Since the project is located in the ecologically, historically, economically, and culturally sensitive area of Myanmar, the activists argue that it could destroy the livelihood system if the river should change or stop its flow in the future ${ }^{19}$.

\section{China's Interests in the Project}

Myanmar has a long borderline with China, especially with the Yunnan Province. It shares 4,060 km long with other Southeast Asian countries such as Myanmar, Laos, and Vietnam ${ }^{20}$. Myanmar serves as the passage for Yunnan province's trade with Southeast Asia and South Asia, uniquely positioned next to the second most populous country, India. Hongwei Fan mentioned that "Yunnan side planned the initiative of "Yunnan International Passage" in 1992. However, it did not have a chance to undertake the blue-print until the 1999 "Western Development" strategy". Early in the 1990s, China and Myanmar introduced the "China Kunming - Myanmar Yangon Ayeyarwaddy River Portage Passage" initiative for the two countries new trading route as the exit to the Andaman Sea or the Bay of Bengal ${ }^{21}$.

This plan included land and water transportation starting from the Bhamo port to the Yangon by using the Ayeyarwaddy River. Both sides even analyzed the possible direction for cargo from Bhamo to Yangon. The China and Myanmar leaders signed this agreement when the Chinese President Jiang Zemin paid a state visit to Myanmar in 1999. According to the agreement, China could use the Ayeyarwaddy River to access the Indian Ocean. However, the Myanmar Military government did not give the green light to Beijing for this project ${ }^{22}$. As the contemporary literature on Myitsone Hydropower Dam project specifies, the Ayeyarwaddy River and China-Myanmar joint projects is concerned, very few authors mention the first project on the Ayeyarwaddy. The current Myitsone Project has received by for more academic attention.

Myanmar has been under harsh sanctions imposed by the West and the US since 1988. Therefore, China has naturally evolved into the foremost economic partner for Myanmar's exports and imports. The period between years 1999 and 2010 was the golden time in the SinoMyanmar relations. Nevertheless, the SPDC leaders have always striven to alleviate Myanmar's over-dependence on China in all sectors. But it was not easy. Consequently, Myanmar has tried to engage its neighbors, primarily India, to diversify Myanmar's economic dependence on China. Still, except for China, most of Myanmar's neighbors supported the anti- 
government armed groups and democracy activists in their border areas. On the other hand, China has always stood by Myanmar's side whenever the SPDC leaders encountered international challenges.

Therefore, SPDC chairman Senior General Than Shwe agreed when Beijing proposed the construction of the hydropower dams project on the Ayeyarwaddy River again in later 2000s. He argued that it was more secure for the country than the previous Cargo line project on the river. At the same time, Myanmar can use electricity from the Myitsone project for the domestic infrastructure construction ${ }^{23}$.

During the Myanmar political transition period, people had developed new concerns about the Myitsone dam project. They began to mobilize when the environmental concerns were voiced and wanted to protect the national landmark. The locals reached their boiling anger point when they learned that about $90 \%$ of electricity would be transmitted directly to the Yunnan Province. On the other hand, the Myanmar experts began to look for alternative joint projects with Beijing since the growth of anti-Chinese sentiment influenced Myanmar ${ }^{24}$. It happened in the early period of President Thein Sein's term (in 2011). Later, President Thein Sein followed his fellow citizens' wishes concerning the Myitsone Hydropower Dam Project by announcing the suspension "in the time of his government" on 30 September $2011^{25}$. However, he did not mention clearly whether the other six projects were going to continue or not in the Mai Hka and Maili Hka rivers. Only a handful of scholars mentioned these projects, most of them do not pay attention to the Mai Hka and Maili Hka projects. Since Mai Hka and Maili Hka flow into the Ayeyarwaddy River, all of six projects can affect the biological system of Myanmar's mother river.

\section{Implications for Sino-Myanmar Relations}

Since the early period of the SPDC government China and Myanmar have experienced turbulent relations. Nevertheless, it happened only on the official government-to-government level. Initially, the Myanmar people thought China was one of the main reasons that helped the military government to stay in power. Therefore, Myanmar citizens openly criticized Chinese investments during the Myanmar political transition period. Zhao Hong stated that "as Myanmar opened up and went through a political transition, Beijing began to feel diplomatically frustrated with the country" ${ }^{26}$. However, Chinese leaders never expected that Myanmar would dare to jeopardize Sino-Myanmar economic partnerships because of the changes in Myanmar domestic policy. Maung Aung Myoe men- 
tioned that "For Beijing, the new Myanmar government was simply old wine in a new bottle, and nothing would be substantially different from the previous military regime. The Chinese government hoped that it could continue to exercise its 'presumed' influence over the new government" 27 .

Since Myanmar entered its new political transition era, western scholars have expressed similar to Maung Aung Myoe's opinion that President Thein Sein's administration was trying to improve ties with Japan, South Korea, the U.S and the EU ${ }^{28}$. These developments have distressed Beijing and its policies on Myanmar. When Thein Sein suspended the Myitsone Project, Chinese concerns reached the highest point. Chinese leaders pointed out that the U.S and Western influence were behind the environmental activists ${ }^{29}$. Consequently, Sino-Myanmar relations have been undeviatingly declining since President Thein Sein's fateful decision to shut down the Myitsone. This shutdown could not be a sole reason behind the decline in state relations. Curiously, another mega Chinese investment into the Letpadaung Taung Copper Mine project was given a green light to redevelop the contract in $2013^{30}$.

Chinese Foreign Minister Wang Yi was the first foreign guest for the NLD government just after two weeks of the NLD coming into power on 5 April $2016^{31}$. According to the South China Morning Post, two foreign ministers also discussed the Myitsone Project on this trip ${ }^{32}$. Also, Daw Aung San Su Kyi, State Counsellor of Myanmar and the leader of NLD government, paid a state visit to China in August 2016 as her first foreign trip as the Union Foreign Minister. Before her trip, she founded the Myitsone Project Investigation Commission staffed with government officers, environmental specialists, and local dignitaries ${ }^{33}$. According to the Myanmar Ministry of Information press release, the commission discussed the Myitsone Dam project with local residents in the Kachin State, CPI and Chinese and Myanmar experts on hydropower dam projects. However, the commission did not give a clear answer on the resumption of the Myitsone project in its final report ${ }^{34}$. Perhaps, Yun Sun stated that Suu Kyi wanted to be fully prepared for her meeting with Chinese leaders when they proposed to discuss the Myitsone Project ${ }^{35}$.

At the same time, the Chinese Ambassador Hong Liang and the CPI delegation visited the Kachin State and met with local officials and residents to discuss the project ${ }^{36}$. Myanmar's environmental activists argued that the Chinese delegation tried to persuade the locals to resume the whole project. Also, during the meeting with Myanmar State Counsellor in Beijing, the Chinese President signified that "China always 
treats the China-Myanmar relationship from a strategic and long-term perspective". Maung Aung Myoe mentioned that "Xi has referred to a "strategic partnership" whenever he has met Myanmar's leaders lately, yet he realizes that the partnership has not met Chinese expectations" ${ }^{\text {"37 }}$. There is no the correct information on how much CPI has already invested in the project. Still, they have already spent a significant amount on the Myitsone Project ${ }^{38}$.

Therefore, the Chinese government has always put it on the agenda whenever they meet Myanmar officials. Meanwhile, it seems that Beijing is trying to use any possible ways to appease the local population. It was apparent when the Representative of the Upper House (Amyothar Hluttaw) from Kachin State admitted that the CPI promised a vast amount of money to him for not halting the project in 2014-2015 . However, official Beijing did not respond to this allegation. This news also soured the Myanmar people's feelings concerning Chinese investments. No Myanmar administration has ever denied the importance of China's role in Myanmar's foreign policy and domestic affairs. On the other hand, every government has tried to balance Beijing influence against other international factors.

From the geo-political standpoint, no one could deny that China is the paramount partner for Myanmar and its national development. Myanmar tries to develop relations with the U.S and the EU, but Myanmar's leaders always have to be aware of the Beijing interests in Myanmar's foreign policy. Since 1988, China has always stood by Myanmar's side whenever Myanmar has had a hard time in the UN. On the other hand, Myanmar was the first country that recognized "Peoples' Republic of China" when it was established in $1949^{40}$.

\section{Conclusion}

China is still as the top investor country in Myanmar. In the first year of Thein Sein's administration, 2011-2012, Chinese FDI in Myanmar reached US\$ 4345.73 million. It was the second-highest amount reached in bilateral trade since $1988^{41}$. After the series of protests against Chinese investments when the Myanmar government followed the public opinion, the FDI from China reached the lowest point with US\$56.16 million in 2013-2014 ${ }^{42}$. When NLD came to power in March 2016, Beijing investment amount reached only US\$ 3328.85 million in 2015$2016^{43}$. It transpired because Beijing signaled its investors the "rising political risk against Chinese investment" in Myanmar ${ }^{44}$. In the 2018-2019 fiscal year, Chinese FDI gained US\$ 634.57 million $^{45}$. Beijing invest- 
ments into Myanmar have never reached again its highest point since 2011.

In his regular press briefing, the spokesperson of China's Foreign Ministry, Hong-Lei argued that "Since the inauguration of the Myitsone Hydropower Project, a huge sum of money has been invested. If the project gets suspended, the loss would go far beyond direct investment and financial expenses" 46 . It seems to be a reasonable sentiment, but Beijing should discuss the Myitsone project with Myanmar's people directly. On the other hand, China has other opportunities to continue investing in Myanmar. If the leaders of two countries rethink the future of Myitsone Project based on mutual interests, it could signify economic cooperation, recovering the two countries relations in the future.

\footnotetext{
${ }^{1}$ Maung Aung MYOE. Myanmar's China Policy since 2011: Determinants and Directions, Journal of Current Southeast Asian Affairs, Vol. 34, No. 2, 2015, pp. 50, URL: https://journals.sub.uni-hamburg.de/giga/jsaa/article/view/872/879.html

${ }^{2}$ Chan, Debby S.W. Asymmetric Bargaining between Myanmar and China in the Myitsone Dam Controversy: Social Opposition Akin to David's Stone against Goliath, The Pacific Review, Vol. 30, No. 5, 2017, pp. 674-691, URL: http://dx.doi.org/10.1080/09512748.2017.1293714

${ }^{3}$ Yun Sun. China's Strategic Misjudgement on Myanmar, Journal of Current Southeast Asian Affairs, Vol. 31, No. 1, 2012, pp. 73-96, URL: https://journals.sub.unihamburg.de/giga/jsaa/article/view/513.html ${ }^{4}$ Laur Kiik. Nationalism and anti-ethno-politics: why 'Chinese Development' failed at Myanmar's Myitsone Dam, Eurasian Geography and Economics, 22 June 2016, Vol. 57, No. 3, 2016, pp. 376, URL:http://dx.doi.org/10.1080/15387216.2016.1198265

${ }_{5}^{5}$ Appendix (2012). Chronology of the Myitsone Dam at the Confluence of Rivers above Myitkyina and Map of Kachin State Dams, Journal of Current Southeast Asian Affairs, Vol. 31, No. 1, pp. 143, URL: https://d-nb.info/1024416801/34

${ }^{6}$ Maung Aung MYOE. Myanmar's China Policy since 2011: Determinants and Directions, Journal of Current Southeast Asian Affairs, Vol. 34, No. 2, 2015, pp. 38, URL:

https://journals.sub.uni-hamburg.de/giga/jsaa/article/view/872/879.html

${ }^{7}$ Chan, Debby S.W. Asymmetric Bargaining between Myanmar and China in the Myitsone Dam Controversy: Social Opposition Akin to David's Stone against Goliath, The Pacific Review, Vol. 30, No. 5, 2017, pp. 679, URL: http://dx.doi.org/10.1080/09512748.2017.1293714 ${ }^{8}$ Chan, Debby S.W. Asymmetric Bargaining between Myanmar and China...

${ }^{9}$ Appendix (2012), Chronology of the Myitsone Dam at the Confluence of Rivers above Myitkyina and Map of Kachin State Dams, Journal of Current Southeast Asian Affairs, Vol. 31, No. 1, pp. 144, URL: https://d-nb.info/1024416801/34

${ }^{10}$ Yun Sun. Chinese Investment In Myanmar: What Lies Ahead?, STIMSON Center, Washington, 16 September 2013, URL: https://www.stimson.org/content/

chinese-investment-myanmar-what-lies-ahead

${ }^{11}$ Laiza is also a city and the Kachin Independent Army's (KIA) headquarter beside the Myanmar-China border. See at A.Mizumo. Eonomic Relations Between Myanmar and China. Chapter in The Myanmar Economy: Its Past, Present and Prospects, Springer, 2016, pp. 212, Table 8.3. URL: https://www.springer.com/gp/book/9784431557340
} 
${ }^{12}$ Laiza is also a city and the Kachin Independent Army's (KIA) headquarter...

${ }^{13}$ Chan, Debby S.W. Asymmetric Bargaining between Myanmar and China in the Myitsone Dam Controversy: Social Opposition Akin to David's Stone against Goliath, The Pacific Review, Vol. 30, No. 5, 2017, pp. 679, URL: http://dx.doi.org/10.1080/09512748.2017.1293714. (accessed: 6.12.2019)

${ }^{14}$ Myitsoneseemankain mar Tayouknà Sarchouthtartà Sarchoutpar Achatalattwe (Information of contract with China in Myitsone Project)-exclusive interview with former Second Minister of Electrical Power U Maw Thar Htwe, 3 May 2019, BBC Myanmar. URL:

https://www.bbc.com/burmese/burma-48155347. (accessed: 5.12.2019)

${ }^{15}$ Laur Kiik. Nationalism and anti-ethno-politics: why 'Chinese Development' failed at Myanmar's Myitsone Dam, Eurasian Geography and Economics, 22 June 2016, Vol. 57, No. 3, 2016, pp. 376, URL: http://dx.doi.org/10.1080/15387216.

2016.1198265. (accessed: 5.12.2019)

${ }^{16}$ Yun Sun, Chinese Investment In Myanmar: What Lies Ahead?, STIMSON Center, Washington, 16 September 2013, pp. 5, URL: https://www.stimson.org/content/

chinese-investment-myanmar-what-lies-ahead (accessed: 4.12.2019)

${ }^{17}$ Lewis Owen, Surinder M. Bhardwaj, Thomas R, Leinbach. Irrawaddy River: River, Myanmar. Encyclodaedia Britannica, inc. February 2019, URL:

https://www.britannica.com/place/Irrawaddy-River (accessed: 4.2.2020)

${ }^{18}$ Chan, Debby S.W. Asymmetric Bargaining between Myanmar and China in the Myitsone

Dam Controversy: Social Opposition Akin to David's Stone against Goliath, The Pacific Review, Vol. 30, No. 5, 2017, pp. 679, URL: http://dx.doi.org/10.1080/09512748.2017.1293714. (accessed: 6.12.2019)

${ }^{19}$ Maung Aung MYOE, Myanmar's China Policy since 2011: Determinants and Directions, Journal of Current Southeast Asian Affairs, Vol. 34, No. 2, 2015, pp. 38 URL:

https://journals.sub.uni-hamburg.de/giga/jsaa/article/view/872/879.html. (accessed: 3.12.2019)

${ }^{20}$ Hongwei Fan, China's "Look South": China-Myanmar Transport Corridor, Ritsumeikan International Affairs, Vol.10, 2011, pp. 44, Institute of International Relations and Area Studies, Ritsumeikan University, URL: https://www.oilseedcrops.org/wp-

content/uploads/2014/02/Chinas-Look-South-to-the-Myanmar-China-Transport-Corridor.pdf (accessed: 6.12.2019)

${ }^{21}$ Hongwei Fan, China's "Look South": China-Myanmar Transport Corridor...

${ }^{22}$ Hongwei Fan, China's "Look South": China-Myanmar Transport Corridor...

${ }^{23}$ Interview with an adviser to President Thein Sein via Phone (He requested not to mention his name)

${ }^{24}$ Maung Aung MYOE, Myanmar's China Policy since 2011... pp. 38

${ }^{25}$ Appendix (2012), Chronology of the Myitsone Dam at the Confluence of Rivers above Myitkyina and Map of Kachin State Dams, Journal of Current Southeast Asian Affairs, Vol. 31, No. 1, pp. 150, URL: https://d-nb.info/1024416801/34. (accessed: 5.12.2019)

${ }^{26}$ Zhao Hong, Japan and China: Competing for Good Relations with Myanmar, The Journal of East Asian Affairs, Vol. 28, No. 2, pp. 8, Fall/Winter 2014, Institute for National Security Strategy, URL: https://www.jstor.org/stable/43233875. (accessed: 1.12.2019)

${ }^{27}$ Maung Aung MYOE, Myanmar's China Policy since $2011 \ldots$ pp.50

${ }^{28}$ Egreteau, Renaud. "Foreign Policy and Political Changes in Post-Junta Myanmar (2018)." Ganguly, Sumit, Joseph C. Y. Liow and Andrew Scobell, Eds., The Routledge Handbook of Asian Security [2nd Edition], London \& New York: Routledge, Pp. 303, 2018, URL: https://www.academia.edu/35992026/Foreign_Policy_and_Political_Changes_in_Postjunta_Myanmar_2018_(accessed: 2.12.2019)

${ }^{29}$ Yun Sun. Myanmar in US-China Relations, Great Powers and the Changing Myanmar.

STIMSON center, No. 3, June 2014, URL: https://www.stimson.org/sites/

default/files/file-attachments/Myanmar_Issue_Brief_3.pdf. (accessed: 3.12.2019) 
${ }^{30}$ Maung Aung MYOE, Myanmar's China Policy since 2011... pp. 46.

${ }^{31}$ Timeline: China-Myanmar Relations, The Irrawaddy, 13 January 2020, URL:

https://www.irrawaddy.com/specials/timeline-china-myanmar-relations.html (accessed: 21.2.2020)

${ }^{32}$ Nectar Gan. Chinese Foreign Minister Wang Yi meets Aung San Suu Kyi in Myanmar as Beijing takes proactive approach to country's new government, South China Morning Post, 5 April 2016, URL: https://www.scmp.com/news/china/diplomacy-defence/article/1933701/ chinese-foreign-minister-wang-yi-meets-aung-san-suu-kyi (accessed: 21.2.2020)

${ }^{33}$ VOA Burmese, URL: https://burmese.voanews.com/a/myitsone-damcommission/3461610.html. [Myitsone Seemankain laelarsonesannyay Kawmashin Phwatsee (founded Myitsone Investigation Commission), Htet Aung, 12 August 2016, VOA Burmese] (accessed: 5.12.2019)

${ }^{34}$ The Investigation Commission for Hydropower Dam Projects on Ayayarwaddy River Released it's the First Report, Ministry of Information, The Republic of the Union of Myanmar, 11 Nov 2016

${ }^{35}$ VOA Burmese, URL: https://burmese.voanews.com/a/myitsone-dam-commission/ 3461610.html. [Myitsone Seemankain laelarsonesannyay Kawmashin Phwatsee (founded Myitsone Investigation Commission), Htet Aung, 12 August 2016, VOA Burmese (accessed: 5.12.2019)

${ }^{36}$ Jennifer Y.J. Hsu, Burmese Civil Society Challenges China's Development Assistance in Myanmar, Gilded Age, ANU Press, 2018, pp.179, URL:

https://www.jstor.org/stable/j.ctvgd1hr.39. (accessed: 1.12.2019)

${ }^{37}$ Maung Aung MYOE, Myanmar's China Policy since 2011... pp. 47.

${ }^{38}$ Maung Aung MYOE, Myanmar's China Policy since 2011... pp. 47.

${ }^{39}$ URL: https://www.facebook.com/1510161869098690/videos/2172256646370902/. (accessed: 5.12 .2019 )

${ }^{40}$ Maung Aung Myoe, In The Name of Pauk-Phaw: Myanmar's China Policy Since 1948, Institute of Southeast Asian Studies, Singapore, 2011

${ }^{41}$ Myanmar State Directorate of the Investment and Company Administration official Website, URL: https://www.dica.gov.mm/en/taxonomy/term/38 (accessed: 20.12.2019)

${ }^{42}$ Myanmar State Directorate of the Investment and Company...

${ }^{43}$ Myanmar State Directorate of the Investment and Company...

${ }^{44}$ Yun Sun, Chinese Investment In Myanmar: What Lies Ahead?, STIMSON Center, Washington, 16 September 2013, pp. 2, URL: https://www.stimson.org/ content/chinese-investment-myanmar-what-lies-ahead (accessed: 4.12.2019)

${ }^{45}$ Myanmar State Directorate of the Investment and Company Administration official Website, URL: https://www.dica.gov.mm/en/taxonomy/term/38 (accessed: 20.12.2019)

${ }^{46}$ CPI: Mutually Beneficial and Double Winning China-Myanmar Myitsone Hydropower Project, China Daily Newspaper, 03-10-2011, http://www.chinadaily.com.cn/china/201110/03/content_13835493.htm

Статья поступила в редакцию 11.05.2020, принята к публикации 20.05.2020. 